\title{
THE CITY AND THE MANUFACTURING SENSITIVITY IN OVERMODERNITY
}

\author{
A cidade e a fabricação do sensível na sobremodernidade
}

Antonio Carlos Queiroz Filho*

\begin{abstract}
Resumo
Este artigo versa sobre o papel da política das imagens e seus desdobramentos nos modos de dizer-ver-sentir a cidade e a vida urbana contemporânea. Como objetivo principal, visa discutir conceitualmente a potência da sensibilidade, via imaginação e poesia, como formas de ampliar os horizontes explicativos da Ciência Geográfica. Para isso, buscou-se apontar o papel desses valores como parâmetros investigativos importantes para os estudos sobre a cidade e os fluxos da vida urbana (mobilidades), na tentativa de compreender os desafios e paradoxos existentes no contexto de mundo sobre-moderno.
\end{abstract}

Palavras-chave: Cidade, Experiência, Imagem, Imaginação, Mobilidade, Sobremodernidade.

\begin{abstract}
This article examines the role of the politics of images and their developments in the ways of saying-seeing-feeling the city and contemporary urban life. Its main objective is to conceptually discuss the power of sensitivity, through imagination and poetry, as forms of expanding the explanatory horizons of Geographic Science. To that end, the role of these values as important investigative parameters for studies on the city and the flows of urban life (mobilities) is discussed in an attempt to understand the challenges and paradoxes that exist in the context of an overmodern world.
\end{abstract}

Key words: City; Experience; Iimage; Imagination; Mobility; Overmodernity

\section{Résumé}

Cet article a pour but de sensibiliser la population au rôle de la politique d'image mais aussi à son développement afin de mieux sentir la ville et la vie urbaine contemporaine. L'objectif principal est de discuter sur la puissance de la sensibilité à travers l'imagination et la poésie comme un moyen d'élargir les horizons de la science géographique explicative. Pour cela, nous avons essayé de mettre l'accent sur le rôle important de ces valeurs comme un paramètre important de la recherche. En effet elles peuvent servir, lors d'études sur la mobilité urbaine par exemple, à essayer de comprendre les enjeux et paradoxes dans le contexte d'un monde moderne.

Mots-clés: Ville; Expérience; Image; Imagination; Mobilité; Surmodernité. 


\section{INTRODUCTION}

We considered an initial and important movement when seeking to problematize the role of images and the imagination in contemporary times, which, more specifically, consists of reflecting on the relationship between aesthetics and politics and their ramifications for the production and constitution of what we call "spatial imagination", directly referencing the studies of the English geographer Doreen Massey (2008) in her book For Space.

In particular, we are interested in examining the flows of contemporary urban life (mobilities) and, from there, thinking about how to erase a spatial imagination that is already so compromised by processes that regulate and stabilize thought and action. Therefore, the question posed here concerns the ways that have already been established as well as many other possible ways of saying and seeing the city, which, in turn, places us in the midst of the complex issue of how this affects contemporary urban life. Therefore, imagination and poetry function as beacons of this process.

The imagination that is our starting point is exactly that which causes the automatism of sensitivity and of our ability to act and think, from which it is of interest to produce others. The question that is fitting now is the following: What would this "other" imagination be made of? Thus, poetry enters the scene, especially that which Manoel de Barros addresses. He teaches us about the material of poetry:

The things that are discarded / Are very important / — like a man discarded. Manoel de Barros, Matéria de Poesia [Material of Poetry].

This "discarded man" is he who writes with twisted words; he is the product of twisted thought/ imagination. If, for de Barros, "poetry is the madness of words", what could be said about Poetic Geography or a poetry of the city and about a spatial imagination made of poetry? If the madness of words is the wisdom of men who do not have a commitment to grammar, the madness of this Geography may be exactly in that which it (and so many other world orthographies) is "discarded".

...before an announcement / Stated as though constative / Stains. Stains of images / Celebrations of language. Manoel de Barros, O Livro de Pré-Coisas [The Book of Pre-Things].

If we think of Geography as an image-factory, i.e., a place of mass production and automation, and if we think that the promotion of "aesthetic acts as the configuration of experience [...] give rise to new ways of feeling and induce new forms of political subjectivity" (RANCIÈRE, 2009, p. 11), then what we are ultimately wishing for is to give this "image" new uses, new meanings, new politics, in short, new powers to act.

It serves not only for the image-factory but also for the image-city, especially if we consider what the Spanish philosopher and educator Jorge Larrosa says when he points to the need for us to recognize a world context "characterized by the plural character of truth, by the character constructed from reality, and by the poetic and political character of language" (LARROSA, 2010, p. 164).

And in this thinking about the city, what would happen to our imaginations if:

- we thought of the city as though it were a text, a poem, a song, a work of art?

- which immediately leads us to a second question: any text, poem, song, or work of art? (as though they were archetypes or models for solving these questions). Notably, we have real interest in those that operate in the tension between the "power of the constants" and the "power of variation" (DELEUZE AND GUATTARI, 1995, p. 50), between the reactive and the creative imagination.

It is in the intimacy of the language and in the bias of sensitivity that a "city as a smaller power" arises, an intensive city that proliferates life as a meeting of words, images, and emotions, as hope 
and resistance - a character-city, made of meetings: text-city, poetry-city, music-city, art-city, all mixed together, folded together, one talking about the other, all being the same. A city invented to no longer fit in the repeated gesture of a single way of saying the city.

\section{ON SAYING THE CITY: EXPERIENCE AND SENSITIVITY}

A northeasterner named Jesus / Sought after night and day in São Paulo / Turks in Germany / A Palestinian serving coffee in Israel / African-Asians on the streets of Seattle / And yet it is still difficult / To see a multiracial kiss in Hollywood / The world migrates and is met with borders / The keys are the same / Samuel L. Jackson and Charlton Heston / Have the same colour as violence / Both believe in weapons / Both open doors with dollars and euros / A kiss on the beloved homeland / Next to a burnt flag / An arm's an arm, the arm of a rejected land / Arms jumping the walls of the world / Of the future for employment, arms of refugees / Despite everything, for a moment / They land in a state of hallelujah / Without religion exile, ah, exile. Exile (Marisa Monte in collaboration with F.U.R.T.O)

The music of the Brazilian singer Marisa Monte gives melody to many reductionist clichés that have been questioned within a saying-city guided by contemporaneity or, if we prefer, by overmodernity, which enshrines, in its scope, "a superabundance of causes that complicate the analysis of the effects" (AUGÉ, 2010, p. 15).

In particular, what intensifies this challenge concerns an irresolute set of paradoxes that are set before us. The very music cited reveals this: simultaneously with an intensification of circulation and flow, observed by the intensification of multiplicity and hybridity as potentiality, there is a diametrically opposing force generating stigmatizations and standardizations of these same relationships, thus creating unique perspectives and overdetermined ways of seeing and saying.

However, there is admittedly an effort to attempt to address a scenario that recognizes, as the Italian philosopher Gianni Vattimo shows us, the prospect that we are facing a context of "irresistible pluralization [that] renders any unilinear view of the world and history impossible" (VATTIMO, 1992, p. 12). In a direct dialogue with the French philosopher Jean François Lyotard (1993), he argues about the dilution of the supreme perspective and the great narratives and emphasizes:

Overturning the idea of a central reality of history, the world of generalized communication explodes like a multiplicity of "local" rationalities that finally speak up for themselves; they are no longer repressed and cowed into silence by the idea of a single true form of humanity. (VATTIMO, 1992, p. 15)

This discursive multiplicity, this generalized communication, this taking of voices that before had been silenced or ignored - the freeing of differences - constitutes a feeling that the world is constantly changing, simultaneously as conservative forces, which seek to reconfigure it starting from the "nostalgia for a solid, unitary, and stable reality", arise (VATTIMO, 1992, p. 14).

In this clash, the so-called "emancipation" has had a denomination, which also does not fail to be paradoxical: that we are facing a paradigm that advocates on behalf of "a world where we can theoretically do everything without displacing ourselves", or, in the words of Zygmunt Bauman, for the sake of the "freedom to move" (BAUMAN, 1999, p. 8). Simultaneously, this same world is "full of 'abscesses of fixation', whether they be 'territorial or ideological"” (AUGÉ, 2010, p. 16).

It is in Bauman that we observe an explanatory way out for this paradoxical context. He argues that mobility, being a "coveted" value, an "always scarce and unequally distributed commodity, soon becomes the main stratifying factor of our late modern or postmodern times" (BAUMAN, 1999, p. 8). Thus, this makes us think of two instances: mobility as an allegory of spatial thought/ imagination and as the phenomenon driving the contemporary urban experience. It is, therefore, in the relationship between these two aspects that we can think about "saying-city" and effectively problematize the so-called "mobilities paradigm" (URRY, 2007) as something that is effectively emancipatory: 
A mobilities paradigm is not just substantively different, in that it remedies the neglect and omissions of various movements of people, ideas and so on. But it is transformative of social science, authorizing an alternative theoretical and methodological landscape. (URRY, 2007, p. 18)

When Geography changed the name of the discipline from "Geography of Circulation and Transport" to "Geography of Networks and Flows" and, later, to "Geography of Mobility", the issue was not merely semantic. There was clearly an epistemological understanding of this disciplinary field to attempt to accompany the changes and transformations occurring in the world, at their different scales.

Both Augé (2010) and Urry (2007) consider one contextually new aspect in the constitution of this horizon that is now configured: the profusion of information and images. In the contemporary city, we are, at all times, being bombarded by them. As a result, we can highlight two key issues when we think of emancipation from the perspective of Vattimo (1992) and Rancière (2014). Thus, we have two processes being compromised:

a) experience:

The flooding from information and images has confused us, making us think that to be informed is to have knowledge. Vattimo warns that "the very logic of the information 'market' requires its continual expansion and, consequently, demands that 'everything' become an object of communication" (VATTIMO, 1992, p. 12). Perhaps for this reason, the incisive statement made by Larrosa that "Information is not experience" (LARROSA, 2002, p. 21) makes a considerable amount of sense to us. Currently, information, knowledge, and learning have mistakenly become synonyms, as though to learn was nothing other than to acquire and process information (LARROSA, 2002, p. 22).

b) sensitivity:

The compromising of sensitivity refers to the perspective of the "manufacturing of the sensible" and the "distribution of the sensible", from the French philosopher Jacques Rancière. Reflecting on the existing relationships between aesthetics and politics, he explains that "aesthetic acts [are] the configuration of experience" (RANCIÈRE, 2009), and, therefore, in the face of the compromising of experience, we can recognize that we are in the midst of a "stylisation of life" (PELLEJERO, 2009, p. 15).

We live in a time in which automatism, individualism, impersonality, haste, insecurity, and speed are the major hallmarks of contemporary city living. The experience of urban living is losing the ability to "negotiate sense" (BAUMAN, 1999, p. 8). In this context, what would be the emancipatory ideal that we are left with? Vattimo defends the "oscillation, plurality, and, ultimately, the very "principle of reality"' (VATTIMO, 1992, p. 13), whereas Rancière (2014) argues that it is necessary to understand that "looking is also an action that confirms or modifies" that which he calls "the distribution of positions". He states:

Emancipation begins when we dismiss the opposition between looking and acting and understand that the evidence that frames the very relationship between saying, seeing, and doing is part of to the configuration of domination and subjection. (RANCIÈRE, 2014, p. 17)

Thus, we return to the question of what it would mean to think about an emancipatory saying of the city. The anthropologist Massimo Canevacci proposes a way of being in the world that aligns the issues that we are addressing. For him, it is necessary "to find strange all possible familiarity with the city and, simultaneously, become familiar with its many differences" (CANEVACCI, 2004, p. 30), thus making us foreigners, daring us to take other paths, to look from different perspectives, 
highlighting the multiplicities and leaving us captivated by the oddities that surround us, or, in the author's words, to "look obliquely at the superknown" (CANEVACCI, 2004, p. 31).

We can also engage with another perspective, that presented by the French anthropologist Michel Agier (2011) in his book Anthropology of the City. The author proposes a change in the following question: instead of saying "What is the city?", what would happen if we asked "What does the city do?"

Perhaps then we can assume an orientation that takes the city as no longer being "'a thing' that I can see or 'an object' that I can completely grasp" (AGIER, 2011, p. 38), no longer as a "generalizing theoretical abstraction" (AGIER, 2011, p. 20) but rather as something relational and situational because "the very being of the city arises, therefore, not as a piece of data but as a process that is human and alive, whose complexity is the very material of the observation, of the interpretations and practices of making the city"' (AGIER, 2011, p. 39).

We encounter a reverberation of the reflections of Agier when addressing the idea of the "polyphonic city" of Massimo Canevacci. In the author's words, the polyphony

Designates a certain methodological choice to "give voice to many voices", thus experiencing a polyphonic approach with which one can represent the same object-urban communication. The polyphony is in the object and in the method. (CANEVACCI, 2004, p. 17-18)

When saying that polyphony is in the object and in the method, Canevacci echoes the sentiment of Urry (2007) and points us to the methodological and conceptual need to see, in the sense of recognizing, and how to make seen a multiplicity that arises, in both the material and the discursive plane, in terms of both experience and sensitivity, which are, so to speak, the "recitation of movements" (TAVARES, 2013, p. 170) of a way of thinking and feeling the city and its many possible orthographies.

Tavares discusses this "recitation of movements, perhaps in the same way as we refer to the recitation of poems" (TAVARES, 2013, p. 170). We can think, then, about a poetry of the inhabiting of the contemporary city, not as a verifiable fact but as a combative potentiality in the midst of a flow of passivity, automatism, and repetition, that is, against the mere reproduction of an experience of mechanized metropolitan living that hijacks places and converts our relationship with them into a principle of mere commodity-consumption. The poetry of the inhabiting is, so to speak, that which exists because a Man relinquishes being completely individual. He decides to interact with others (TAVARES, 2013, p. 172).Given the above, we recognize how much "we are, of the city, an inseparable part. We are voices, eyes, mouths, words, desires, thoughts..." (QUEIROZ FILHO; DAMIANI; BORGES, 2013, p. 72). Additionally, with this, we authorize ourselves to claim a slow urbanism, an aesthetic of the walking, a posture within the world that is taken in the detailed observation, in the problematization of that which is set before us. We make available a way of "saying and seeing the city" as plurality and a way of thinking the city, seeing the city, and feeling the city as a pulsating body.

\section{ON DOING THE CITY: IS IT POSSIBLE?}

Against the orthodox is how we could title the book The Death and Life of Great American Cities by the American writer Jane Jacobs. Her words, more than just scientific theory, are food for doing the city from the perspective of an "attack on current city planning and rebuilding" (JACOBS, 2011, p. 1), and she concludes her reasoning by stating: "I will mainly be writing about common, ordinary things" (JACOBS, 2011, p. 1).

Although this practice is, for Jacobs, a way of looking at cities as a "great laboratory", a "testing" place where you can test urban planning theories (JACOBS, 2011, p. 5) — which we can consider a utilitarian perspective - it causes the idea of thinking about the world based on direct contact with 
the flow of life to reverberate in us; furthermore, it demands of us, among many things, a change of scale: to look closer and less from above. Is this possible?

When Massey (2008) states, for her, "theory comes from life", it sounds transformative. This was a type of "spiritual state" that accompanied us silently. Although the writer and poet Clarice Lispector (1998, p. 64) had stated "I feed delicately on trivial daily routine", it was with Doreen Massey that we could give voice to a conceptual and methodological perspective of investigating the world - doing the city - based on what many consider to be banal, placing it always in the condition of investigative indigence, often qualifying it as unworthy of becoming the object of scientific concern. By contrast, this is what interests us: being inhabited by the "secret harmony of disharmony", "I want not what is done, but what is tortuously still being done" (LISPECTOR, 1998, p. 12). Is it possible?

How can I explain it to you? I will try. It's that I'm perceiving a crooked reality. Seen through an oblique cut. Only now have I sensed the oblique of life. I used to only see through straight and parallel cuts. (...) Oblique life is very intimate. (LISPECTOR, 1998, p. 62-63)

From this perspective, intimacy, that is, the proximal nature of urban life, has us interested in a particular way, and "obliquity" (CANEVACCI, 2004) has become a perennial challenge, just as it was inspiring for Canevacci when he left Rome and was faced with the immensity of the city of São Paulo, the "patchwork city" (CANEVACCI, 2004, p. 10). We share this "discovery of the look" in which to look "obliquely at the superknown" is an almost inalienable premise to the understanding of polyphony as a real possibility. Is it possible?

Both with the poet Manoel de Barros and the Portuguese writer Gonçalo M. Tavares, we have learned to fight the formulations of a prefabricated doing-the-city, to recognize as method to "err, circulate, hesitate around that which has no solution" (TAVARES, 2013, p. 28) as well as to "brush the words" until they turn into an "unobject" (BARROS, 2010b).

Here, then, is a doing-the-city-poem. It relates to a non-capture by the "pigeon-holed word. The one that cannot change place" (BARROS, 2010b, p. 43) or serve as a covering for the great explanatory theories and their "drawers", which, in the words of Tavares, are "verbal organizers" (TAVARES, 2013, p. 28):

We think, in fact, by concepts, but the drawers that have multiple communication with each other-with holes, with slopes, with obvious passages and other more secret passages - are fun; drawers that hold not solid but liquid materials, materials whose essence is movement, materials that are not in one place: they circulate between places. (TAVARES, 2013, p. 29)

Similarly, as Manoel de Barros sweetly tells us: "The size of things has to be measured by the intimacy we have with things" (BARROS, 2010b, p. 67). Is it possible? Canevacci did not yet have intimacy with São Paulo when he saw it for the first time. How could he then be inclined towards polyphony? Because it was him. To be privileged? No. To be oblique, given to being willing to launch oneself into the unknown. He allowed himself to be lost. In detachment, he launched himself into the "flow of emotions" (CANEVACCI, 2004, p. 14).

I am convinced that it is possible to develop a more or less accurate urban communication methodology, with the following condition: to want to lose oneself, to take pleasure in this, to accept being a foreigner, uprooted $\neg$, and isolated ... (CANEVACCI, 2004, p. 15)

This was his intimacy and his circularity: it is possible. 


\section{ON FEELING THE CITY: POEM-SPACE}

We resume the dialogue with Doreen Massey. Indeed, we want to draw a parallel between the first part of her book, From Space (2008), and the beautiful work of Ítalo Calvino, Invisible Cities (1990). Both treat the city as spatial imagination. Massey first explains to us the fundamental role of the reports in the "voyages of discovery".

In this seemingly innocent discursive practice, upon analysing the case of the Aztecs, Massey informs us that the inhabitants to be conquered were "devoid of history", as though they had been "immobilized" awaiting the arrival of their conquerors. The political outcome of discourses such as this is to perpetuate an imagination that takes space as a surface. Doing this:

Such a space makes it more difficult to see in our mind's eye the histories that the Aztecs too have been living and producing. What might it mean to reorientate this imagination, to question that habit of thinking of space as a surface? (MASSEY, 2008, p. 23)

For Calvino, the cities encountered in the travels of Marco Polo, at the behest of Emperor Kublai Khan, were subjected to a discourse that was based on space as a surface-which was Zora-space - that "which has the quality of remaining in your memory" for this simple reason: everyone knew it by heart because it had been "forced to remain motionless and always the same, to be more easily remembered" - or Tamara-space - the space made of "images of things that mean other things"; for example, the "pincers indicate the tooth-drawer's house". Symbols teach us that:

Your gaze scans the streets as though they were written pages: the city says everything you must think, makes you repeat her discourse, and while you believe you are visiting Tamara, you are only recording the names with which she defines herself and all her parts.

There are, undoubtedly, other ways to imagine space, as Doreen Massey claims. In Calvino, there is the example of Dorotea-space, stated both for the detailed description of its shapes, objects, and mathematically calculated data and for the memory-map of the camel-driver who guided Polo. Zaira-space communicates its story through the "corners of the streets" and the "gratings of the windows", that is, "the measurements of its space and the events of its past"; for example:

the rips in the fish nets and the three old men seated on the dock mending nets and telling each other for the hundredth time the story of the gunboat of the usurper, who some say was the queen's illegitimate son, abandoned in his swaddling clothes there on the dock.

The past of the imagination and the poetry contained in this story of the three old men and in the others referred to herein as other ways of imagining space is present at the instant when word and image merge into a memory, which could be said, poetically, is an "invented memory" (BARROS, 2010), created from contempt, old pieces of wood, some crawling insects, wet earth, and a naively curious gaze that places all that into a box of useless objects and mixes them. After that, it is no longer possible to distinguish the seeing, saying, doing, and feeling: everything comes to be.

\section{ON MANUFACTURING THE SENSITIVE: DIVER-CITY}

Unlike the invented-memory of Manoel de Barros, the prefabricated imagination would be the "false" term from the expression "everything that I do not invent is false". It is that which prevents or potentially diminishes our poetic-creative capacity and is constituted as the experience itself. The American urban planner Kevin Lynch draws attention to the act of looking at cities. However commonplace and repeated our daily practice may be, Lynch tells us that "Nothing is experienced 
by itself but always in relation to its surroundings, the sequences of events leading up to it, the memory of past experiences" (LYNCH, 2010, p. 1).

Prefabricated urban landscapes remove us from this multiple and inventive possibility. Paraphrasing Lynch (2010), we should not take into account the urban landscapes (cities) as things in themselves but the way in which they are experienced and produced. After all, "A landscape whose every rock tells a story may make difficult the creation of fresh stories" (LYNCH, 2010, p. 7).

Is there a landscape more prefabricated than those of the large luxury condominiums? The American urban planner and historian Mike Davis (2009) refers to them as "sterilized sites", "verdant homesteads", participants in a logic that, according to the author:

Evokes much of the past evolution of tract-home Southern California. However, the developers are not just repackaging the myth (the good life in the suburbs) for the next generation; they are also pandering to a new, burgeoning fear of the city. (DAVIS, 2009, p. 40)

The production of fear also has a ready-made formula, as in the example of the analysis performed by Davis in the book City of Quartz when he discusses how the "myth of the desert sanctuary" was shattered by a series of violent acts that occurred after New Year's Eve 1990 (DAVIS, 2009). However, there is another precast method that Davis addresses very well: the image of the city. He reports:

One of my new Llano campañeros said that L.A. was already everywhere. They had watched it every night in San Salvador, in endless dubbed reruns of I Love Lucy and Starsky and Hutch, a city where everyone was young and rich and drove new cars and saw themselves on television. (DAVIS, 2009, p. 47)

Such spectacular images of Los Angeles were the great mobilizing spatial imagination, not only from the dreams of the many who went there, such as the illegal migrants who place themselves at risk crossing the "overprotected" borders or the stars of Hollywood cinema and their acts of refuge and self-seclusion. This discursive practice is what legitimized the city as an image, produced in the interval between existence and becoming, which is the same as the between of Clarice Lispector when she says: "I want an invented truth" (LISPECTOR, 2008, p. 13).

It is in this manner that the reflections that assume poetry as their constituents arise. They propose to think of the city in the context of overmodern mobility, beyond the functionalist and mechanistic perspective. The main characteristics of contemporary city living and the main paradoxes of the mobility paradigm come to serve as "material of poetry". This is the premise of the poetry of Manoel de Barros. It does not have the commitment to the "truth", not even intending to explain anything. As he himself states: "poetry serves to enlarge the world".

Additionally, it would be no different with a Geography that envisages "enlarging the world". From the experience captured by the clichéd images, the landscape instantaneously and automatically consolidated in our memories frays apart. We increase our imaginative horizons and thus provoke the grammar of the image to say otherwise.

\section{FINAL CONSIDERATIONS}

To analyse the contemporary city is also to understand the role that images play in current urban life, given a world context that is dominated by the narratives and discourses of visuality. In the words of Marc Augé, this context corresponds to what he calls the "ideology of the system of globalization, an ideology of visibility, self-evidence, and the present" (AUGÉ, 2010, p. 16).

This aspect of the production and circulation of images has changed the very manner in which different areas of knowledge have sought to think of the city as a category that is beyond concrete material aspects. It is what John Urry emphasizes when he says: 
I thus seek to bring into vision how social life presupposes many issues of movement and non-movement, of forced movement and of chosen fixity, of people, images, ideas and objects. (URRY, 2007, p. 17 -italics added)

By emphasizing images and ideas as key participants in the contemporary context, a world scenario is taken as a starting point in which the images that come from the various media (film, television, photography, the internet, etc.) participate, without precedents, in our way of thinking-acting (ALMEIDA, 2000; OLIVEIRA JR., 2009):

Image today has been transformed into the commodity par excellence, the object of production, circulation, and consumption, fantastically realizing the old axiom: create not only a commodity for the subject but also create subjects for the commodity. This is now the status of image. (NOVAES, 2005, p. 10)

We assume the understanding of the invented space, for example, through photographic cameras and through television narratives, as a necessary part of delving into issues that pass both by the "sale" of a spatial imagination through products, which unfolds in spatial and discursive practices that are increasingly more linked to the establishment of new understandings of the City-Image relationship as a place-commodity / landscape-product of a rhetoric of global capitalism.

For sale - a style, a concept, a symbology, and a way of thinking and acting in the world, which is always linked to the consumption of a particular product; and this consumption is linked to a worldwide community. The functionality loses focus and what will count, in fact, is what or who the individual becomes for the world when consuming a given functionality. (QUEIROZ FILHO, 2010, p. 6)

Milton José de Almeida argues that television programmes "express in images and words various values and messages and they participate in different ways in the great mythical construction of contemporary society" (ALMEIDA, 2000, p. 4) and that they do so by promoting that which he calls "visual catechism", given the role assigned to television images as being true "visual celebrations of ways of seeing and being in the world" (ALMEIDA, 2000, p. 5).

Thus, when we examine the production and circulation of images, such as large landscapes and narrative territories, we are on the path of the argument of Oliveira Jr. when he speaks of a "unique landscape" that occurs largely "by the logic of the commodity, making the world a set of places to be consumed" (OLIVEIRA JR., 2008, p. 2).

Therefore, we are in the midst of the challenge of attempting to understand which "unique landscape" is being built and the logic of the spatial imagination and its ramifications for the imagination of the political (MASSEY, 2008) and for the manifestations of the main paradigm that has guided the production of the contemporary city, namely, overmodern mobility.

This spatial imagining, in the words of Massey herself, is not taken from the political imagining; "it affects the way we understand globalization, the way we approach cities, the way we develop, and practice, a sense of place" (MASSEY, 2008, p. 15). The investigatory effort employed concerns the attempt to try to understand the ramifications of the politics of the look, which now constitutes itself, and that which has been regarded as the "new politics of spatiality" (MASSEY, 2008), which inevitably involves new material and symbolic configurations for mobility.

All of these aspects configure a web of issues that have fuelled what we can call the "mobility of thought", which particularly results in a concern (conceptual and methodological) that addresses the political role of images and their visual narratives in the midst of an analytical horizon that has been clouded but, simultaneously, has gained new tones and new designs.

Here, the word "new" is not used in the sense of "replacement", the succession of a possible method/object by another. Instead, it is from the perspective of expanding the explanatory possibili- 
ties of the human and social sciences as a whole as they take on new issues, themes, and reflections as the agenda of their epistemological and ontological scope.

It is as though we are facing a great conceptual landscape that has been set in motion or that has even assumed motion as its greatest power. The implication is that, to a large extent, its driving force has been placed more strongly before other gazes and other perspectives. In the terms of the poet Manoel de Barros (2010b), this would be to make Contemporary Geography a "stretcher of horizons", therefore, a Geography that takes the world as a creating and creative power for itsmany-orthographies.

\section{BIBLIOGRAPHIC REFERENCE}

ALMEIDA, Milton José de. A Educação Visual na Televisão Vista Como Educação Cultural, Política e Estética. Pró-Posições, volume 10 (2), p. 9-25, Campinas, 1999.

AGIER, Michel. Antropologia da Cidade: lugares, situações, movimentos. Trad.: Graça Índias Cordeiro. São Paulo: Terceiro Nome, 2011.

BARROS, Manoel de. Memórias Inventadas: a segunda infância. São Paulo: Planeta, 2010a.

BARROS, Manoel de. Manoel de Barros: poesia completa. Rio de Janeiro: Record, $2010 \mathrm{~b}$.

BAUMAN, Zygmunt. Globalização: as consequências humanas. Trad.: Marcos Penchel. Rio de Janeiro: Zahar, 1999.

CALVINO, Ítalo. As Cidades Invisíveis. Trad.: Diogo Mainardi. São Paulo: Companhia das Letras, 1990. CANEVACCI, Massimo. A Cidade Polifônica: ensaios sobre a antropologia da comunicação urbana. Trad.: Cecília Prada. São Paulo: Nobel, 2004.

DAVIS, Mike. Cidade de Quartzo: escavando o futuro em Los Angeles. Trad.: Marco Rocha e Renato Aguiar. São Paulo: Boitempo, 2009.

DELEUZE, Gilles; GUATTARI, Félix. Mil Platôs: capitalismo e esquizofrenia 2, vol. 02. Trad.: Ana Lucia de Oliveira e Lúcia Cláudia Leão. São Paulo: Ed. 34, 1995.

DELEUZE, Gilles; GUATTARI, Félix. Kafka: por uma literatura menor. Trad.: Cíntia Vieira da Silva. Belo Horizonte: Autêntica Editora, 2014.

JACOBS, Jane. Morte e Vida de Grandes Cidades. Trad.: Maria Estela Heider Cavalheiro. São Paulo: WMF Martins Fontes, 2011.

LARROSA, Jorge. Pedagogia Profana: danças, piruetas e mascaradas. Trad.: Alfredo Veiga-Neto. Belo Horizonte: Autêntica, 2010.

LISPECTOR, Clarice. Água Viva. Rio de Janeiro: Rocco, 1998.

LYNCH, Kevin. A Imagem da Cidade. Trad.: Jefferson L. Camargo. São Paulo: WMF Martins Fontes, 2010.

LYOTARD, Jean-François. O pós-moderno. Trad. Ricardo Corrêa Barbosa. Rio de Janeiro: José Olímpio, 1993.

MASSEY, Doreen. Pelo Espaço: uma nova política da espacialidade. Trad.: Hilda Pareto Maciel e Rogério Haesbaert. Rio de Janeiro: Bertrand Brasil, 2008.

NOVAES, Adauto. A imagem e o espetáculo. In: NOVAES, Adauto (Org.) Muito Além do Espetáculo. São Paulo: Senac São Paulo, 2005.

PELlEJERO, Eduardo. A Postulação da Realidade: filosofia, literatura, política. Trad.: Susana Guerra. Lisboa: Edições Vendaval, 2009.

OLIVEIRA JR, Wancesláo M. de. A educação pelas imagens e suas geografias: grafar o espaço, educar os olhos. Rumo a geografias menores. Pro-posições, Vol. 20 (3), Campinas, 2009.

QUEIROZ FILHO, Antonio Carlos; DAMIANI, Hadassa Pimentel; BORGES, Rafael Fafá. Rasuras e Experimentações Apontamentos sobre Imagem - Cidade - Experiência, Entre-Lugar, Nº7, p. 67-85, ano 4, Dourados, MS, 2013. 
QUEIROZ FILHO, Antonio Carlos; DAMIANI, Hadassa Pimentel; BORGES, Rafael Fafá. (2010) Geografias Televisivas: imaginação espacial a partir de comerciais e reportagens de jornal. Anais XVII ENG. Disponível em: $<$ http://www.agb.org.br/evento/download.php?idTrabalho=3573>Acesso em: 27/02/2016 RANCIÈRE, Jacques. A Partilha do Sensível: estética e política. Trad.: Mônica Costa Netto. São Paulo: Ed. 34, 2009.

RANCIÈRE, Jacques. O Espectador Emancipado. Trad.: Ivone C. Beneditte. São Paulo: WMF Martins Fontes, 2014.

TAVARES, Gonçalves M. Atlas do Corpo e da Imaginação: teoria, fragmentos e imagens. Alfragide, PT: Caminho, 2013.

URRY, John. Mobilities. Malden, MA: Polity Press, 2007.

VATTIMO, Gianni. A Sociedade Transparente. Trad.: Hossein Shooja e Isabel Santos. Lisboa: Relógio D’Água, 1992.

Submitted july 2016 Accepted august 2016 